\title{
PENGEMBANGAN PERANGKAT PEMBELAJARAN BERBASIS MASALAH MEGGUNAKAN MEDIA MOODLE UNTUK MENINGKATKAN KETERAMPILAN BERPIKIR KRITIS MAHASISWA PADA MATERI GELOMBANG
}

\author{
Lovy Herayanti ${ }^{* 1}$, Syifaul Gummah ${ }^{1}$, Bq. Azmi Sukroyanti ${ }^{1}$, Gunawan ${ }^{2}$, Muh. Makhrus ${ }^{2}$ \\ ${ }^{1}$ Program Studi Pendidikan Fisika, IKIP Mataram \\ ${ }^{2}$ Program Studi Pendidikan Fisika, Universitas Mataram \\ *Email: lovyherayanti@ikipmataram.ac.id
}

\begin{abstract}
E-learning is learning process through electronic media, especially internet. E-learning enables learners to learn or possess science no matter when and where. The goal of this study was to develop Moodle in problem-based learning in order to improve learners' critical thinking skills. . The study was a research and development $(R \& D)$ study conducted in four stages, i.e. preliminary study, developing design, testing Moodle as media for problem-based learning, and result dissemination. Subjects of this study were students of physic education program of Faculty of Mathematics and Science Education of IKIP Mataram who enrolled in Wave course. Data on critical thinking skills is collected through tests, where tests have been validated by experts. The results of the study indicate an increase in students' critical thinking skills. Moreover, students gave positive response towards the use of Moodle developed as media in problem-based learning.
\end{abstract}

Keywords: moodle, problem-based learning, critical thinking skill, concepts of wave

\section{PENDAHULUAN}

Fisika merupakan salah satu cabang ilmu pengetahuan alam (IPA) yang mendasari perkembangan teknologi maju dan konsep hidup harmonis dengan alam. Sebagai ilmu yang mempelajari fenomena alam, fisika juga memberikan pelajaran yang baik kepada manusia untuk hidup selaras berdasarkan hukum alam. Salah satu materi dalam pembelajaran fisika yaitu materi gelombang. Materi gelombang terdiri dari konsep yang abstrak dan pada umumnya sulit untuk dipelajari (Serway \& Jewett, 2009). Pembelajaran sains belum memberi kesempatan maksimal kepada peserta didik untuk mengembangkan kreativitas, bahan ajar kurang kontekstual, dan keterampilan proses belum nampak, serta belum memanfaatkan teknologi untuk pembelajaran (Wuryastuti, 2008), hal ini menjadi kendala dalam pengembangan kemampuan peserta didik untuk menguasai konsep yang diajarkan.
Sementara itu permasalahan pembelajaran gelombang belum sepenuhnya berlandaskan pada hakekat sains sebagai proses, sehingga keterampilan-keterampilan ilmiah masih sangat minim baik di level menengah maupun level perguruan tinggi khususnya calon guru fisika.

Dewasa ini perkembangan teknologi informasi komputer telah merambah dunia pendidikan. Dengan memasuki dunia online, pendidik dapat memperoleh berbagai informasi yang diperlukan untuk memenuhi kebutuhan bahan pembelajaran. E-Learning merupakan proses pembelajaran melalui media elektronik terutama internet. Saat ini, $e$ Learning menjadi media pembelajaran yang digunakan selain tatap muka dikelas. Hal ini disebabkan karena e-Learning memungkinkan peserta didik untuk dapat belajar maupun mendapatkan ilmu pengetahuan kapan pun dan dimana pun dia berada. E-Learning juga menjadi alternatif bagi peserta didik yang 
mengalami kejenuhan belajar dalam tatap muka di kelas (Arianti, 2012).

Berpikir merupakan keterampilan dalam melaksanakan suatu pekerjaan, yang mendorong kecerdasan untuk bekerja. Keterampilan berpikir tidak dapat berkembang secara alamiah. Kaitannya dengan kritis, konsep berpikir sering disebut sebagai berpikir kritis. Berpikir kritis telah lama menjadi pendekatan dalam melakukan pembelajaran. John Dewey sebagai seorang filusuf dan psikolog dikenal sebagai orang yang telah lama mengenalkan konsep berpikir kritis. Dewey memperkenalkan berpikir kritis sebagai “berpikir reflektif" (Fisher, 2003).

Kemampuan berpikir tingkat tinggi seperti berpikir kritis, berpikir kreatif dan pemecahan masalah dianggap keterampilan yang diperlukan bagi individu abad ke-21 Oleh karena itu, penting dan penting untuk memeriksa dimensi ini dari sudut pandang yang berbeda untuk mengembangkan gagasan tentang cara terbaik untuk membekali individu dengan keterampilan ini dan untuk membuatnya lebih mudah menghadapi teknologi dan situasi yang muncul (Kalelioglu dan Gülbahar. 2014).

Menurut Bassham et al. (2008), berpikir kritis berarti berpikir dengan jelas dan tepat. Dengan kata lain berpikir kritis merupakan istilah umum yang mencakup sejumlah keterampilan kognitif dan disposisi intelektual yang diperlukan untuk mengidentifikasi, menganalisis dan mengevaluasi argumen secara efektif agar dapat menemukan dan mengatasi prasangka pribadi dan bias, dapat merumuskan dan menyajikan alasan yang meyakinkan dalam mendukung kesimpulan, dan dapat membuat keputusan yang masuk akal dan tepat tentang apa yang dilakukan dan diyakini. Persoalan di atas, khususnya dalam mengajarkan keterampilan berpikir kritis dapat diatasi dengan melatih peserta didik berpikir kritis melalui kegiatan pembelajaran.

Media dengan menggunakan teknologi multimedia, berbagai media konvensional yang ada dapat diintegrasikan ke dalam satu jenis media interkatif, seperti media teks (papan tulis), audio, video, yang jika dipisahkan akan membutuhkan lebih banyak media. Adanya peningkatan keterampilan berpikir kritis setelah penggunaan multimedia interaktif menunjukkan bahwa adanya pengaruh penggunaan multimedia interaktif terhadap peningkatan tersebut (Husein, Herayanti, \& Gunawan. 2017).

Dosen sebagai tenaga pendidik perlu merancang pembelajaran yang dapat melatih kemampuan berpikir kritis peserta didik agar mencapai keberhasilan dalam belajar. Ada banyak pendekatan, strategi, metode dan model yang dapat diterapkan untuk melatih kemampuan berpikir kritis peserta didik dalam pembelajaran, salah satunya alternatif adalah dengan menggunakan model Problem Based Learning (PBL).

Sejalan dengan kebutuhan pendidik dalam mengatasi permasalahan proses pembelajaran pada matakuliah gelombang, maka dirasa perlu adanya suatu inovasi baru dalam pengembangan media pembelajaran yang mampu dikemas agar pembelajaran lebih menarik, interaktif dan efektif serta efesien dalam pemanfaatnya. Kemudian berdasarkan kenyataan seperti tersedianya kemudahan akses internet untuk menerapkan e-learning. Keuntungan bagi pendidik yang membuat bahan ajar online menggunakan LMS moodle adalah kemudahan. Hal ini karena pendidik tidak perlu mengetahui sedikitpun tentang pemprograman website, sehingga waktu dapat dimanfaatkan lebih banyak untuk memikirkan content pembelajaran yang akan disampaikan. 
Secara umum penggunaan media pembelajaran menggunakan media moodle akan menciptakan proses pembelajaran lebih menarik dan interaktif. Selain itu tingkat pemahaman peserta didik terhadap materi pelajaran lebih baik karena peserta didik sendiri yang memilih dan aktif mencari informasi tentang materi yang dipelajari.

Moodle adalah sebuah Open Source Course Management System (CMC), yang berarti tempat belajar dinamis menggunakan model berorientasi objek, juga dikenal sebagai Learning Management System (LMS) atau Virtual Learning Environment (VLE). Moodle merupakan sebuah program aplikasi yang dapat merubah media pembelajaran ke dalam bentuk web. Manfaat dari pengunaan LMS menggunakan Moodle secara online sangat penting, diantaranya untuk mengatasi keterbatasan frekuensi tatap muka antara mahasiswa dengan dosen. Dalam penggunaan moodle versi online, urutan langkah yang telah dilakukan pada tahun pertama adalah dimulai dengan instalasi program moodle secara online melalui laman web lovy.ikipmataram.ac.id, kemudian dilanjutkan dengan melakukan manajemen data pada setting profile dan administrator, manajemen course, dan diakhiri dengan enroll user sesuai dengan fungsi user dalam perkuliahan (Herayanti, et al. 2017).

Moodle berfungsi sebagai alat bantu yang efektif dalam menyediakan fasilitas pembelajaran karena dilengkapi dengan fiturfitur penting penunjang pembelajaran seperti tugas, quiz,chat, kolaborasi, serta fitur utama yang dapat meng-upload berbagai format materi pembelajan serta lebih mudah untuk dipahami karena informasi yang di sajikan tidak hanya berbentuk tulisan tetapi juga gambar (Sampurno, dkk. 2015).
Fitur yang terdapat dalam moodle sesuai dengan kelas online dan lebih baik digunakan untuk tambahan dari pembelajaran melalui tatap muka di kelas. Moodle menyediakan banyak pilihan fitur. Semua fitur yang tersedia dibuat untuk mendukung kegiatan pembelajaran sebagaimana mestinya. Dalam penelitian ini fitur yang digunakan antara lain activities, resources, forum, quizzes dan assignments (Herayanti, et al. 2017).

Pembelajaran berbasis masalah, yang juga sering disebut Problem-Based Learning (PBL), merupakan model pembelajaran yang memberdayakan peserta didik untuk melakukan penyelidikan, memadukan teori dan praktik, serta menerapkan pengetahuan dan keterampilan untuk mengembangkan sebuah solusi praktis atas suatu problem tertentu (Savery, 2006). Pembelajaran berbasis masalah merupakan salah satu jenis model pembelajaran yang bersifat learnercentered atau pembelajaran yang berpusat pada siswa, di samping Project-Based Learning, Case-Based Learning, dan InquiryBased Learning (Eggen \& Kauchak, 1996; Savery, 2006).

Pembelajaran berbasis masalah (Problem Based Learning) merupakan salah satu model pembelajaran yang berasosiasi dengan pembelajaran kontekstual. Pembelajaran berbasis masalah memberi pengertian bahwa dalam pembelajaran peserta didik dihadapkan pada suatu masalah, yang kemudian diharapkan melalui pemecahan masalah peserta didik belajar keterampilanketerampilan berpikir yang lebih mendasar. Menurut Boud \& Felleti (1998) menyatakan pembelajaran berdasarkan masalah (Problem Based Learning) adalah suatu pendekatan untuk membelajarkan peserta didik dalam mengembangkan keterampilan berfikir dan 
keterampilan memecahkan masalah, sekaligus melatih kemandirian peserta didik.

Esensi PBL adalah menyuguhkan berbagai situasi bermasalah yang autentik dan bermakna kepada peserta didik, yang berfungsi sebagai batu loncatan untuk investigasi dan penyelidikan peserta didik. PBL berusaha membantu peserta didik untuk menjadi pembelajar yang independen dan selfregulated. Dibimbing oleh pendidik yang senantiasa memberi semangat dan reward ketika mengajukan pertanyaan dan mencari sendiri solusi untuk berbagai masalah rill, kelak peserta didik belajar untuk melaksanakan tugasnya secara mandiri (Arends, 2012).

IKIP Mataram merupakan satu diantara beberapa Perguruan Tinggi Swasta (PTS) yang bergerak dalam ranah pendidikan. Sebagai bentuk penyesuaian diri dan institusi terhadap perkembangan teknologi, IKIP Mataram sejak tahun 2010 telah menyediakan sarana dan prasarana penunjang layanan internet di dalam kampus, baik menggunakan kabel Local Area Network (LAN) maupun ketersediaan area hotspot. Kondisi ini memberikan peluang bagi IKIP Mataram untuk mengembangkan moodle sebagai platform media pembelajaran online bagi para dosen dan mahasiswa.

Media bukanlah satu-satunya komponen penentu keberhasilan dalam proses pencapaian hasil belajar. Penggunaan model pembelajaran yang tepat, metode yang akurat, pendekatan pengajaran yang memberikan dampak signifikan juga harus mendapat perhatian, terutama oleh para pengajar, guru maupun dosen. Diantara hasil belajar yang dapat diamati dan diukur ketercapaiannya adalah penguasaan konsep dan keterampilan berfikir kritis. Menurut Trisdiono (2013), Partnership for $21^{\text {st }}$ Century Skills mengidentifikasi kecakapan abad 21 meliputi: berpikir kritis, pemecahan masalah, komunikasi dan kolaborasi.

\section{METODE PENELITIAN}

Penelitian ini termasuk Research and Development (R\&D) (Gall, Gall \& Borg, 2003). Research and Development merupakan suatu proses atau langkah-langkah untuk mengembangkan suatu produk baru atau menyempurnakan produk yang telah ada yang dapat dipertanggungjawabkan. Perlakuan yang dilakukan yaitu penggunaan perangkat pembelajaran dengan menggunakan media moodle berbasis masalah yang sudah divalidasi oleh ahli untuk meningkatkan keterampolan berpikir kritis peserta didik. Secara garis besar langkah penelitian dan pengembangan yang dikembangkan terdiri atas empat tahapan yaitu: studi pendahuluan, pengembangan desain, pengujian perangkat pembelajaran berbasis masalah menggunakan media moodle, serta diseminasi hasil. Instrumen yang digunakan berupa tes keterampilan berpikir kritis dalam bentuk uraian sebanyak 10 soal, serta angket untuk mengetahui respon mahasiswa terkait pembelajaran yang diikuti. Subjek dalam penelitian ini adalah mahasiswa jurusan pendidikan fisika FPMIPA IKIP mataram yang mengikuti matakuliah Gelombang.

\section{HASIL DAN PEMBAHASAN}

Media pembelajaran moodle berbasis masalah yang dikembangkan memiliki beberapa karakteristik yang sangat erat kaitannya dengan kegiatan pembelajaran. Dalam penelitian ini, dikembangkan media pembelajaran moodle berbasis masalah yang merupakan suatu website pembelajaran. Terdapat materi, bahan ajar dan evaluasi bagi mahasiswa yang disajikan dalam bentuk 
digital sehingga terjadi perubahan sistem pembelajaran teacher center menjadi student center. Media pembelajaran moodle berbasis masalah yang dikembangkan dalam penelitian ini terdiri atas gambar, animasi, serta simulasi interaktif yang berkaitan dengan materi gelombang. Evaluasi ini dibuat dengan menggunakan fitur quizzes yang tersedia didalam moodle. Adapun kelebihan fitur quizzes yaitu pendidik dapat mengatur batas waktu untuk mengerjakan soal yang diberikan, sehingga mahasiswa dituntut untuk mengerjakan setiap soal dengan sungguhsungguh.

Berpikir kritis adalah kemampuan belajar yang harus diajarkan pada peserta didik karena kemampuan ini sangat diperlukan dalam kehidupan (Schafersman, 1991). Sebelum pembelajaran mahasiswa diberikan tes awal untuk mengetahui keterampilan berpikir kritis awal yang dimiliki. Selanjutnya, mahasiswa mengikuti pembelajaran dengan penggunaan media moodle berbasis masalah pada matakuliah gelombang. Pada akhir pembelajaran, mahasiswa diberikan tes akhir untuk mengetahui hasil akhir dan peningkatan berpikir kritis mahasiswa. Hasil penelitian menunjukkan adanya perbedaan keterampilan berpikir kritis yang ditinjau dari tes awal dan tes akhir mahasiswa. Peningkatan mahasiswa diketahui dengan menggunakan uji rata-rata. Gambar 1 di bawah ini menyajikan hasil penelitian mengenai perbedaan skor rata-rata tes awal dan tes akhir mahasiswa pada empat pokok bahasan pada matakuliah gelombang yaitu sifat umum gelombang, superposisi gelombang, gelombang bunyi dan interferensi gelombang.

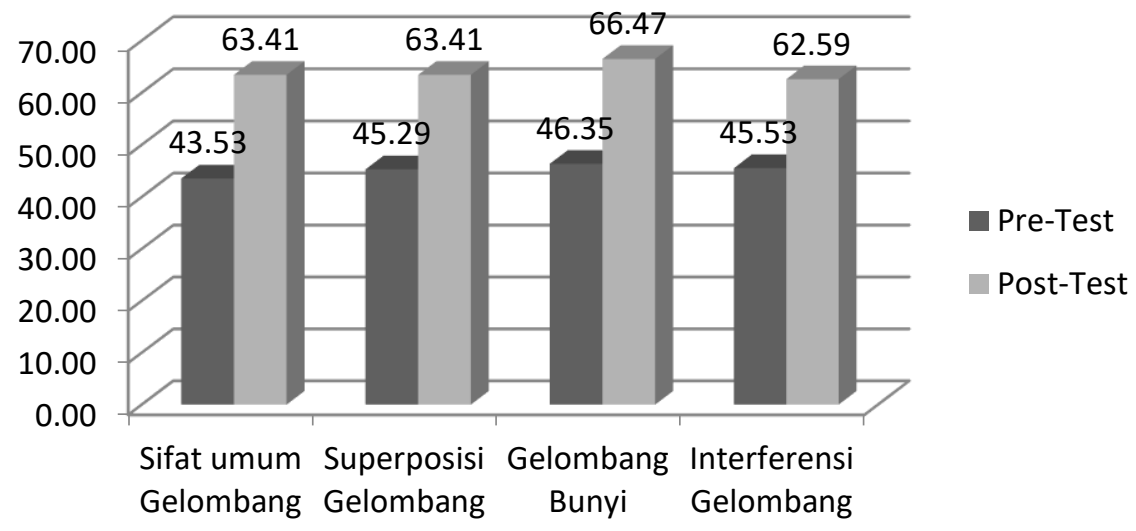

Gambar 1. Perbedaan Skor Rata-Rata Tes Awal dan Tes Akhir Keterampilan Berpikir Kritis Mahasiswa

Gambar 1 di atas menunjukkan bahwa skor rata-rata tes awal berpikir kritis pada masing-masing pokok bahasan yaitu untuk pokok bahasan sifat gelombang sebesar 43.5, superposisi gelombang sebesar 45.3, gelombang bunyi sebesar 46.4 dan interferensi gelombang sebesar 45.5. Setelah diberikan perlakuan dengan media moodle berbasis masalah maka keempat pokok bahasan mengalami peningkatan masing-masing yaitu pada pokok bahasan sifat gelombang sebesar 63,4, superposisi gelombang sebesar 63,4, gelombang bunyi sebesar 66,5 dan interferensi gelombang sebesar 62,6. Peningkatan tertinggi dapat dilihat pada pokok bahasan sifat gelombang. Hal ini dapat dipahami 
karena materi pada pokok bahasan sifat gelombang merupakan materi yang diberikan pada pertemuan awal, konsep-konsep serta persamaan dalam materi tersebut belum terlalu rumit sehingga mahasiswa dapat lebih mudah memahami konsep tersebut.

Berdasarkan analisis data dapat disimpulkan bahwa secara keseluruhan mahasiswa mengalami peningkatan dalam keterampilan berpikir kritis. Hal ini sesuai dengan hasil penelitian Herayanti et al. (2017) yang menyatakan bahwa mahasiswa yang mengikuti perkuliahan menggunakan media berbasis moodle secara signifikan mengalami peningkatan pada hasil belajarnya. Putra (2013) mengungkapkan bahwa penilaian autentik dengan program moodle mampu meningkatkan hasil belajar siswa yang meliputi segi kognitif, psikomotor dan afektif. Hasil penelitian Andrews (2008) juga menjelaskan bahwa media moodle berhasil mendukung penyelenggaraan kolaborasi pengajaran dan pembelajaran di empat universitas di Australia.

Hasil olah data penelitian menunjukkan adanya perbedaan peningkatan keterampilan berpikir kritis pada masingmasing pokok bahasan yang ditinjau dari tes awal dan tes akhir peserta didik. Tes awal diberikan sebelum penggunaan moodle dalam pembelajaran untuk mengetahui keterampilan berpikir kritis awal yang dimiliki peserta didik. Selanjutnya, peserta didik mengikuti pembelajaran dengan penggunaan moodle berbasis masalah. Pada akhir pembelajaran, peserta didik diberikan tes akhir untuk mengetahui hasil akhir dan peningkatan keterampilan berpikir peserta didik.

Penelitian tentang berpikir kritis pada konsep listrik statis bagi mahasiswa yang pernah dilakukan menunjukkan adanya pengaruh positif terhadap model pembelajaran tersebut. Peningkatan yang diperoleh menggunakan pembelajaran berbasis masalah berbantuan simulasi komputer lebih tinggi secara signifikan dibandingkan dengan mahasiswa yang memperoleh pembelajaran konvensional. Dosen dan mahasiswa memberikan tanggapan positif terhadap model pembelajaran berbasis masalah berbantuan simulasi komputer pada materi listrik statis. Model pembelajaran berbasis masalah memberikan pengaruh positif dalam upaya meningkatkan keterampilan berpikir kritis mahasiswa (Herayanti, habibi. 2015)

Peningkatan keterampilan berpikir kritis peserta didik diketahui dengan menggunakan uji N-gain. Gambar 2 berikut menyajikan hasil penelitian mengenai perbedaan skor N-gain peserta didik berdasarkan masing-masing pokok bahasan pada matakuliah gelombang. Peningkatan keterampilan berpikir kritis peserta didik diketahui berdasarkan hasil uji $\mathrm{N}$-gain. Berdasarkan Gambar 2 pada grafik N-gain dapat diketahui bahwa pada pokok bahasan pertama yaitu sifat umum gelombang memperoleh skor tertinggi yaitu 0.75 superposisi gelombang sebesar 0,70, gelombang bunyi sebesar 0,60 dan interferensi gelombang sebesar 0,64. Perolehan skor Ngain keempat pokok bahasan ini menunjukkan bahwa keempat pokok bahasan tersebut mengalami peningkatan keterampilan berpikir kritis yang termasuk dalam kategori tinggi dan sedang. Untuk pokok bahasan pertama termasuk dalam kategori tinggi sedangkan pada pokok bahasan kedua, ketiga dan keempat berkategori sedang walaupun peningkatannya tidak berbeda secara signifikan. Berdasarkan hasil pengamatan, hal ini terjadi karena dalam mengikuti perkuliahan, utamanya perkuliahan online banyak mahasiswa mengalami kendala teknis 
dan belum tahu fitur-fitur yang tersedia dalam portal e-learning yang dalam hal ini digunakan learning management system (LMS) moodle. Banyak mahasiswa belum berpartisipasi dalam forum diskusi online yang disediakan. Mereka mendownload emodul yang diberikan tanpa berbagi tanggapan terhadap isi dari e-modul. Dalam konteks ini, e-modul belum dimanfaatkan atau diekplorasi secara optimal oleh mahasiswa. Upaya pemecahan yang ditempuh terkait dengan masalah ini adalah mensosialisasikan fitur-fitur moodle yang bisa dikelola mahasiswa, mengintegrasikan permasalahan yang diberikan pada modul menjadi bahan diskusi pada forum, menetapkan bahwa mahasiswa dianggap hadir di kelas online jika telah mendownload materi, berpartisipasi di forum diskusi dan mengerjakan kuis online, serta memberikan skor pada mahasiswa bukan hanya pada yang ikut kuis tetapi juga bagi yang berpartisipasi dalam kegiatan forum diskusi yang disediakan. Pembelajaran dalam kelompok PBL secara online berpengaruh signifikan terhadap peningkatan kemampuan berpikir kritis peserta didik (Kalelioglu, F., \& Gülbahar, Y. 2014).

Hasil uji hipotesis penelitian menunjukkan adanya perbedaan yang signifikan antara tes awal dan tes akhir. Hal ini dapat diketahui dari hasil uji $t$ yang memberikan nilai $\mathrm{t}$ hitung sebesar 2.37 dan $\mathrm{t}$ tabel sebesar 2.04.

Media pembelajaran fisika berbasis moodle yang dikembangkan berbentuk sebuah website pembelajaran yang dapat diakses. Media pembelajaran berbasis moodle yang dikembangkan berisi materi juga dilengkapi dengan contoh soal dan tampilan animasi untuk membantu mahasiswa dalam menguasai setiap konsep yang dijelaskan. Tampilan animasi tersebut terbukti membantu mahasiswa untuk memahami konsep-konsep abstrak dengan lebih baik. Hal ini sesuai dengan penelitian Gunawan et al (2013) yang menemukan bahwa visualisasi melalui animasi komputer membantu mahasiswa untuk inferensi logika dan membangun konsep fisika lebih baik dibandingkan mahasiswa lainnya yang belajar secara konvensional.

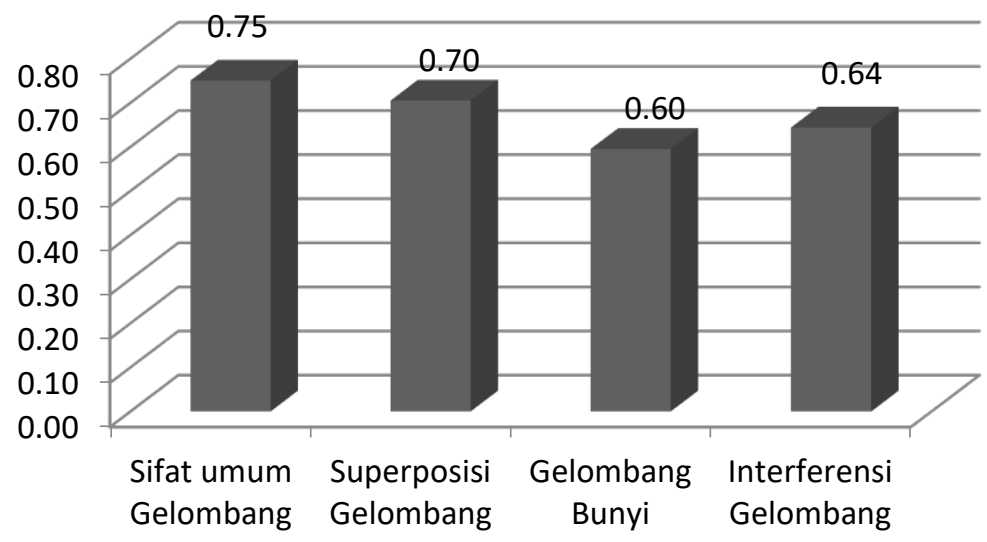

Gambar 2. N-gain Keterampilan Berpikir Kritis untuk masing-masing pokok bahasan gelombang

$\begin{array}{lll}\text { Tanggapan mengenai media } & \text { setelah semua proses pembelajaran selesai } \\ \text { pembelajaran moodle berbasis masalah } & \text { dilaksanakan. Hasil angket mahasiswa } \\ \text { diperoleh dari angket tanggapan mahasiswa. } & \text { menunjukkan bahwa mahasiswa memberikan } \\ \text { Angket ini diberikan kepada mahasiswa } & \text { tangggapan positif terhadap desain, }\end{array}$


kemudahan penggunaan dan peran media pembelajaran moodle berbasis masalah dalam matakuliah gelombang. Pembelajaran dengan menggunakan media moodle berbasis masalah dirasakan efektif oleh mahasiswa dalam mengatasi kesulitan belajar yang mereka alami. Hal ini ditunjukkan dari nilai rata-rata yang diperoleh sebesar 4.20 dengan kategori baik, kemudian dari aspek kemenarikan nilai rata-rata sebesar 4.50 dengan kategori sangat baik dan kemudahan penggunaan media 4.60 dengan kategori sangat baik. Pada kolom tanggapan, secara umum mahasiswa senang dengan adanya media moodle berbasis masalah yang dikembangkan karena memberikan kemudahan dalam mengakses materi pembelajaran gelombang. Selain itu adanya gambar, animasi dan simulasi interaktif membuat proses pembelajaran dalam kelas menjadi lebih menyenangkan dan tidak membosankan. Mahasiswa juga memberikan saran agar media moodle berbasis masalah ini dapat digunakan sebagai media dalam proses pembelajaran untuk matakuliah yang lain. Hasil yang diperoleh dijadikan sebagai dasar untuk menyimpulkan bahwa pembelajaran menggunakan media moodle berbasis masalah dalam proses pembelajaran dapat melatih mahasiswa lebih mandiri karena mahasiswa akan lebih aktif mencari materi serta menyelesaikan tugastugas yang diberikan. Selain itu dapat mempermudah dalam mengakses materi pembelajaran dimana saja dan kapan saja.

Beberapa penelitian lain menunjukkan bahwa pembelajaran online seperti penggunaan media berbasis komputer seperti penggunaan moodle, e-learning dan media virtual lainnya dapat meningkatkan hasil belajar mahasiswa. Gunawan et al. (2018) mengungkapkan bahwa penggunaan media berbasis komputer pada tiga sekolah menengah dapat membantu meningkatkan penguasaan konsep fisika baik siswa laki-laki maupun siswa perempuan. Siswa mengalami peningkatan penguasaan konsep pada setiap aspek kognitifnya. Selain itu Gunawan et al. (2016) mengungkapkan bahwa penguasaan konsep siswa yang belajar menggunaan multimedia interaktif lebih tinggi dibandingkan siswa yang belajar tanpa multimedia. Martín-Blas \& SerranoFernández (2009) menyatakan bahwa pembelajaran fisika secara online melalui penggunaan moodle digunakan untuk membantu baik guru dan siswa memiliki ruang virtual di mana mereka dapat berbagi pengetahuan melalui berbagai jenis aktivitas. Pembelajaran fisika online dapat membantu siswa untuk memperkuat kemampuan dan pengetahuan mereka. Respon siswa terhadap pembelajaran tersebut juga sangat baik.

\section{PENUTUP}

Penggunaan media moodle berbasis masalah yang dikembangkan dapat meningkatkan keterampilan berpikir kritis mahasiswa. Hal ini dapat dilihat dari persentase kenaikan pada masing-masing pokok bahasan pada materi gelombang. Dari hasil penelitian diperoleh data berpikir kritis mahasiswa rata-rata sebelum diberikan perlakuan sebesar 45 dan setelah diberikan pembelajaran dengan menggunakan media moodle berbasis masalah rata-rata meningkat menjadi 64. Secara umum mahasiswa memberikan tanggapan yang positif terhadap desain, kemudahan penggunaan dan peran media pembelajaran moodle berbasis masalah dalam matakuliah gelombang. Pembelajaran dengan menggunakan media moodle berbasis masalah dirasakan efektif oleh mahasiswa dalam mengatasi kesulitan belajar yang mereka alami. 


\section{UCAPAN TERIMAKASIH}

Tim peneliti mengucapkan terimakasih yang sebesar-besarnya kepada Direktorat Riset dan Pengabdian kepada Masyarakat, Direktorat Jenderal Penguatan Riset dan Pengembangan Kementerian Riset, Teknologi, dan Pendidikan Tinggi yang telah membiayai penelitian ini melalui skim Penelitian Strategis Nasional Institusi 2018.

\section{REFERENSI}

Arends, R.I. 2012. Learning to Teach Ninth Edition. New York: Mc Graw-Hill Companies, Inc.

Bassham, G. et al. 2008. Critical Thinking: A Student Introduction. 3rd Ed. Singapore: McGraw-Hill Company, Inc.

Husein, S., Herayanti, L., \& Gunawan, G. (2017). Pengaruh Penggunaan Multimedia Interaktif Terhadap Penguasaan Konsep dan Keterampilan Berpikir Kritis Siswa pada Materi Suhu dan Kalor. Jurnal Pendidikan Fisika dan Teknologi, 1(3), 221-225.

Herayanti, Habibi. 2015. Model Pembelajaran Berbasis masalah Berbantuan Simulasi Komputer Untuk Meningkatkan Keterampilan Berpikir Kritis Calon Guru Fisika. Jurnal Materi dan Pembelajaran Fisika (JMPF), 1(1).

Boud \& Felleti. 1998. The Challenge of Problem-Based Learning. Kogan Page. Sydney.

Eggen, P.D \& Kauchak, D.P. 1996. Strategies for Teachers: Teaching Content and Thinking Skill. (Third edition). Boston: Allyn and Bacon.

Fisher, A. 2003. Critical Thinking An Introduction. Camridge University Press.
Gall, M. D., Gall, J. P., \& Borg, W. R. 2003. Educational Research an Introduction. New York: Pearson Education. Inc.

Gunawan, G and Liliasari L 2012 Model Virtual Laboratory Fisika Modern untuk Meningkatkan Disposisi Berpikir Kritis Calon Guru. Jurnal Cakrawala Pendidikan. 31(2)185-199

Gunawan G, Sahidu H, Harjono A and Suranti N M Y 2017 The Effect of Project Based Learning with Virtual Media Assistance on Student's Creativity in Physics. Cakrawala Pendidikan. 36(2) 167-179

Gunawan G, Harjono, A, Sahidu $H$ and Nisrina N 2018, April Improving Students' Creativity Using Cooperative Learning With Virtual Media on Static Fluida Concept. In Journal of Physics: Conference Series. 1006 (1) 012016

Herayanti, L., Habibi, H., \& Fuaddunazmi, M. 2017. Pengembangan Media Pembelajaran Berbasis Moodle pada Matakuliah Fisika Dasar. Jurnal Cakrawala Pendidikan, 36(2).

Kalelioglu, F., \& Gülbahar, Y. 2014. The Effect of Instructional Techniques on Critical Thinking and Critical Thinking Dispositions in Online Discussion. Educational Technology \& Society, 17(1), 248-258.

Martín-Blas T and Serrano-Fernández A 2009 The role of new technologies in the learning process: Moodle as a teaching tool in Physics Computers \& Education. 52(1) 35-44

Sampurno,P.J, dkk. 2015. Implementasi Kurikulum 2013: Moodle (Modular Object Oriented Dynamic Learning Environment) Dalam Pembelajaran Fisika Melalui Lembar Kerja Siswa Pada Materi Optik Di SMA. Jurnal Pendidikan Indonesia, 14(55). Edisi November 2015. ISSN: 1410-2994. 
Herayanti, L., Fuaddunnazmi, M., \& Habibi,

H. 2017. Pengembangan Media Pembelajaran Berbasis Moodle pada Mata Kuliah Fisika Dasar. Jurnal Pendidikan Fisika dan Teknologi, 1(3), 205-209.

Savery, J.R. 2006. "Overview of Problembased Learning: Deûnitions and Distinctions". The Interdisciplinary Journal of Problembased Learning volume 1 (Spring): 918.

Schafersaman, S. D. 1991. Introduction to critical thinking.Websitehttp//www.freeinqu iry.com/critical-thinking.html. Diakses Mei 2014.

Serway, R. A \& Jewett, J. W. 2009. Fisika untuk sains dan teknik. Jakarta: Salemba Teknika.

Trisdiono, Harli. 2013. Strategi Pembelajaran Abad 21. Yogyakarta. Lembaga Penjaminan Mutu Pendidikan Prov. D.I. Yogyakarta. Tersedia online. 